Banking and Financial Regulation chapter for THE OXFORD HANDBOOK OF LAW AND ECONOMICs (forthcoming 2015, Francesco Parisi, ed.).

\title{
BANKING AND FINANCIAL REGULATION
}

Steven L. Schwarcz ${ }^{1}$

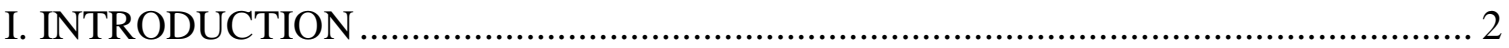

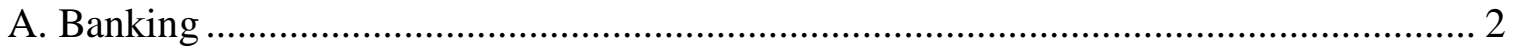

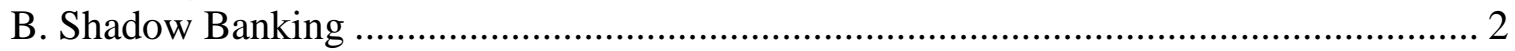

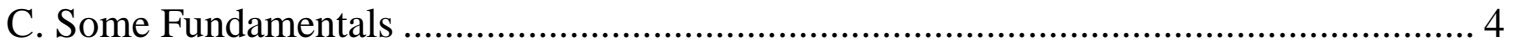

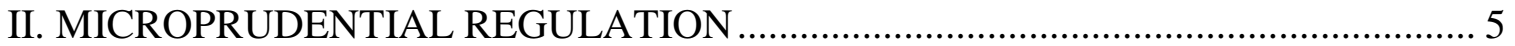

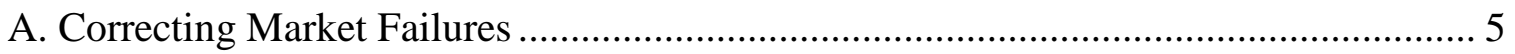

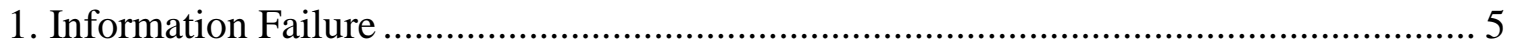

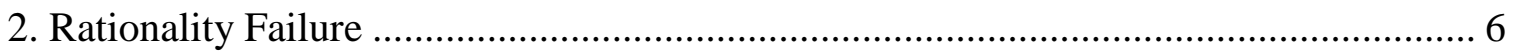

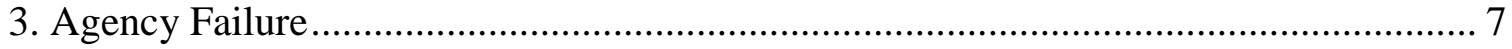

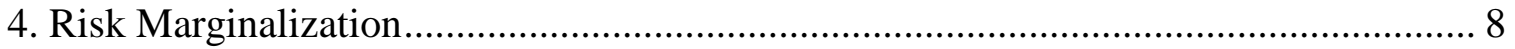

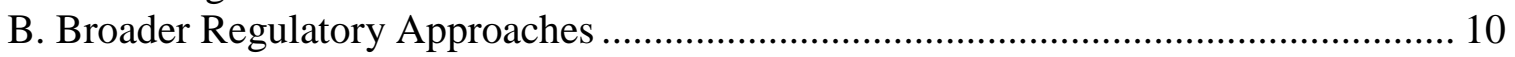

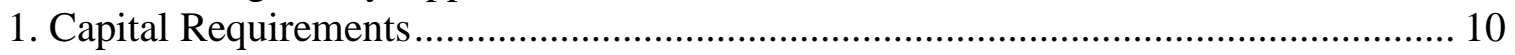

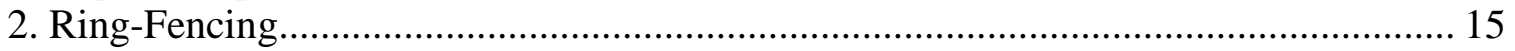

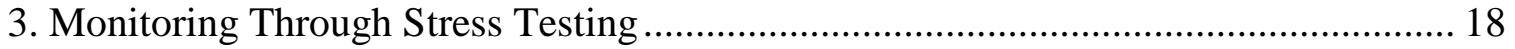

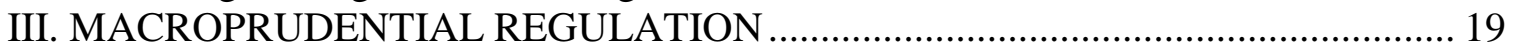

A. Limiting the Triggers of Systemic Shocks............................................................... 19

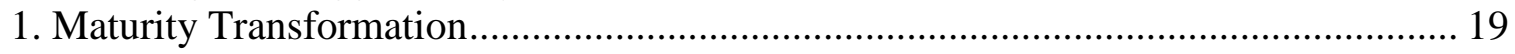

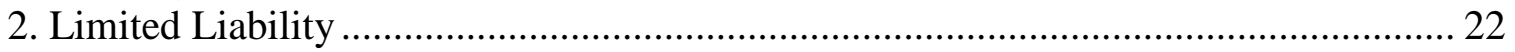

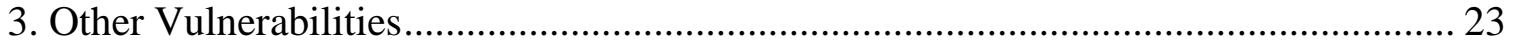

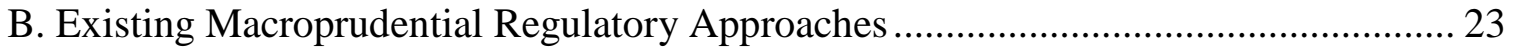

C. Alternative Macroprudential Regulatory Approaches ............................................ 26

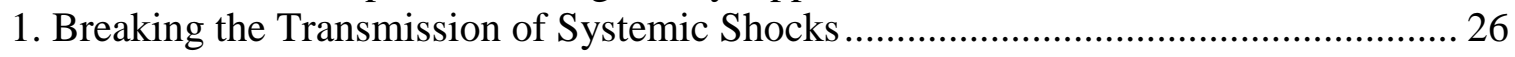

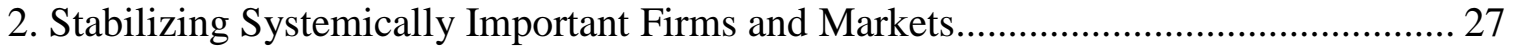

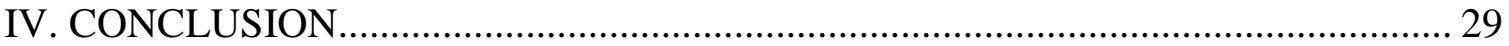

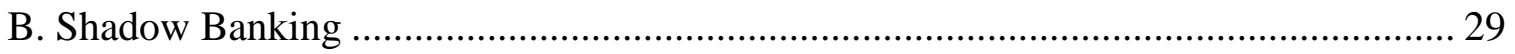

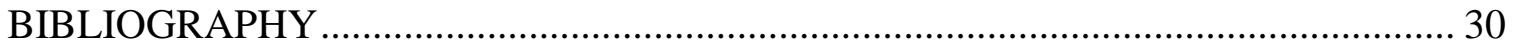

${ }^{1}$ Stanley A. Star Professor of Law \& Business, Duke University School of Law; Founding Director, Duke Global Financial Markets Center. E-mail: schwarcz@law.duke.edu. I thank Lorna Knick, Duke Law School Class of 2015, for excellent research assistance. Portions of this chapter are based in part on the author's forthcoming article, Regulating Financial Change: A Functional Approach, available at http://ssrn.com/abstract=2469467. 


\section{INTRODUCTION}

Banking and financial regulation-which I'll hereafter refer to simply as financial regulation - is needed because the financial system provides functions that are essential to economic development. The principal function is the aggregation of moneys and the allocation thereof for productive projects. Although each nation regulates banking and finance in its own ways, the universal nature of finance drives a natural convergence in the nature of financial regulation. This chapter thus focuses on the universal principles of financial regulation.

\section{A. Banking}

Traditionally, financial regulation focused on banking because banks historically have been the primary entities that have aggregated moneys_-primarily by taking deposits from customers - and then allocated such monies - primarily by making loansto borrowers to invest in productive projects, such as factories. Traditional financial regulation therefore is geared to ensuring that deposit-taking banks can continue to perform these functions efficiently.

\section{B. Shadow Banking}

In recent years, non-banks have increasingly begun replacing (“disintermediating”) traditional banks as the intermediaries of funds - that is, the entities that aggregate moneys and then allocate such monies to firms to invest in productive projects. Shadow banking is a loose term that refers to this process of disintermediation. ${ }^{2}$ The size of the shadow-banking sector-which includes securitization, money-market mutual funds, hedge funds, securities lending, asset-backed commercial paper (“ABCP”)

\footnotetext{
2 See Steven L. Schwarcz, Regulating Shadow Banking, 31 REVIEW OF BANKING \& FINANCIAL LAW 619 (2012-13).
} 
conduits, structured investment vehicles (“SIVs”), and repo financing — was estimated at $\$ 60$ trillion worldwide in December 2011. ${ }^{3}$ More recent estimates suggest an even higher number. ${ }^{4}$

Several reasons, including efficiency and regulatory arbitrage, account for the rapid rise of shadow banking. Shadow banking can be efficient because disintermediation removes traditional banks as the "middleman” of funding, thereby avoiding the profit mark-up that banks charge on their loans. Furthermore, in markets where traditional banks cannot flexibly operate due to overly restrictive regulation, shadow banks can help to fund unmet demands. ${ }^{5}$ The response to Regulation Q in the United States is but one example of this. Regulation Q imposed limits on the interest rates that banks could pay to depositors, creating an unmet demand-especially by institutional depositors-for higher returns. That demand sparked the rise of money-market mutual funds, which offered much higher rates of return than bank deposits. ${ }^{6}$

${ }^{3}$ Philipp Halstrick, Tighter Bank Rules Give Fillip to Shadow Banks, REUTERS (Dec. 20, 2011, 4:17 AM), http://www.reuters.com/article/2011/12/20/ uk-regulation-shadowbanking-idUSLNE7BJ00T20111220 (last visited June 10, 2013).

${ }^{4}$ See Fin. Stability BD., Global Shadow BAnking Monitoring Report (2012), http://www.financialstabilityboard.org/publications/r_121118c.pdf (estimating shadow banking's worldwide assets as $\$ 67$ trillion in 2011). Cf. Sheridan Prasso, Shadow Banking, BLOOMBERG (Apr. 16, 2014), http://www.bloomberg.com/quicktake/shadowbanking/ (reporting that the Financial Stability Board believes that shadow banking grew by $\$ 5$ trillion in 2012 to $\$ 71$ trillion).

5 Timothy Lane, Deputy Governor of the Bank of Canada, "Shedding Light on Shadow Banking," Speech to the CFA Society (June 26, 2013), available at http://www.bis.org/review/r130628g.pdf.

${ }^{6}$ Jonathan Macey, Reducing Systemic Risk: The Role of Money Market Mutual Funds as Substitutes for Federally Insured Bank Deposits, 17 STAN. J.L. Bus. \& FIN. 131, 138 (2011). Sometimes, however, shadow banking can result from pure regulatory arbitrage, without efficiency considerations. For example, in the context of mortgage lending, bank holding companies (BHCs) can lend through affiliated depository institutions (ADIs) or affiliated mortgage companies (AMCs). Whereas ADIs are chartered and subject to banking regulations, including capital requirements, underwriting requirements, and strict accounting practices, AMCs are not subject to any such regulation. Yuliya Demyanyk \& Elena Loutskina, Mortgage Companies and Regulatory Arbitrage 2 (Fed. Res. Bank of Cleveland, Working Paper No. 12-20R 2014), available at http://www.clevelandfed.org/research/workpaper/2012/wp1220r.pdf. By using an AMC 
Regardless of the reasons for the rise of shadow banking, the failure of financial regulation to adequately address that rise "is widely believed to have contributed to the buildup of risks in the financial system in the period leading up to” the 2008 global financial crisis (the "financial crisis”). ${ }^{7}$ Financial regulation must also focus on shadow banking.

\section{Some Fundamentals}

Actual financial regulation tends to be imperfect. Policymakers and regulators tend to respond to the media, which can create distortions by emphasizing what journalists find accessible. Furthermore, after a financial crisis, people naturally want to prevent the next crisis. Regulators, who are themselves usually subject to political shorttermism, typically respond by focusing on preventative regulation, or at least regulation aimed at preventing the next financial meltdown. But that focus is insufficient because it is impossible to always predict the cause of the next financial crisis.

Moreover, financial regulation is often tethered to the financial architecture- the particular design and structure of financial firms, markets, and other related institutionsat the time the regulation is promulgated. Ongoing monitoring and updating of that regulation can be costly, however, and is subject to political interference at each updating stage.

instead of an ADI, BHCs can avoid regulation and can engage in riskier lending practices. Id.

${ }^{7}$ Iman Anabtawi \& Steven L. Schwarcz, Regulating Ex Post: How Law Can Address the Inevitability of Financial Failure, 92 TEXAS LAw REVIEW 75, 85 (2013). See also Ben S. Bernanke, Chairman, Speech at the Russell Sage Foundation and The Century Foundation Conference on Rethinking Finance (April 13, 2012), available at http://www.federalreserve.gov/newsevents/speech/bernanke20120413a.htm (arguing that mortgage lending through AMCs, discussed supra note 6, encouraged risky lending practices that contributed to the financial crisis). 
Notwithstanding these distortions, financial regulation gets enacted. In discussing such regulation, it is useful to distinguish what economists sometimes call microprudential and macroprudential regulation. Financial regulation of the components of the financial system-fundamentally firms and markets - to ensure that they can efficiently perform their underlying economic functions is called microprudential regulation. Financial regulation of the financial system's ability to function as a network within which its components can operate is called macroprudential regulation, and thus the goal of macroprudential regulation is to prevent "systemic" risk. As will be discussed, there is some overlap in these terms.

\section{MICROPRUDENTIAL REGULATION}

As mentioned, microprudential regulation focuses on ensuring that firms and markets, the components of the financial system, can efficiently perform their underlying economic functions. In general, firms and markets operate efficiently absent "market” failures; hence the goal of microprudential financial regulation is to correct market failures.

\section{A. Correcting Market Failures}

1. Information Failure. A key market failure is information failure, which can undermine the reliability of pricing. Funding depends on reliable pricing. Regulation could therefore improve funding by correcting this market failure.

The principal information failure is information asymmetry, referring to parties to a transaction having different amounts of relevant information. For example, an issuer of financial securities usually has more (and better) information than investors in the securities about the risks.

Increasing financial complexity is exacerbating this failure, by undermining disclosure, which since the securities laws of the 1930s has been the chief regulatory tool 
to reduce information asymmetry. Securities laws generally rely on disclosure, but some financial structures are getting so complex that they are effectively incomprehensible. It may even be rational sometimes for an investor to invest in high-yield complex securities without fully understanding them. There may be many reasons for this. For example, the investor simply may not have the staffing to evaluate the securities, whereas failure in invest would appear to — and in fact could—competitively prejudice the investor vis-à-vis others who invest. ${ }^{8}$ Thus, many institutional investors-including even the largest, most sophisticated, firms - bought complex mortgage-backed securities prior to the financial crisis without fully understanding them. ${ }^{9}$

Financial complexity is inevitable. Profit opportunities are inherent in complexity, due in part to investor demand for securities that more precisely match their risk and reward preferences. Regulatory arbitrage increases complexity as market participants take advantage of inconsistent regulatory regimes both within and across national borders. And new technologies continue to add complexity not only to financial products but also to financial markets. Complexity may well be the greatest future challenge for financial regulation.

2. Rationality Failure. Another market failure is rationality failure, which can also undermine the reliability of pricing. Even in financial markets, humans have bounded rationality. In areas of complexity, for example, we tend to overrely on heuristicsbroadly defined as simplifications of reality that allow us to make decisions in spite of our limited ability to process information. Modern finance has become so complex that the financial community routinely relies on heuristic-based customs, such as determining creditworthiness of securities by relying on formalistic credit ratings and assessing risk on financial products by relying on simplified mathematical models. Market participants also follow the herd in their investment choices and are prone to panic. Furthermore, they are unrealistically optimistic when thinking about extreme events with which they have

${ }^{8}$ See Steven L. Schwarcz, Disclosure's Failure in the Subprime Mortgage Crisis, 2008 UTAH LAW REVIEW 1109, 1113-15 (2008).

${ }^{9}$ Id. at 1110. 
no recent experience, devaluing the likelihood and potential consequences of those events. Because human nature cannot be easily changed, there are limited regulatory solutions to the problem of rationality failure.

3. Agency Failure. This market failure generally refers to the misalignment of the interests of principals and their agents. Scholars have long studied inefficiencies resulting from conflicts of interest between managers and owners of firms. There also is a much more insidious principal-agent failure: the intra-firm problem of secondary-management conflicts. The nub of the problem is that secondary managers are almost always paid under short-term compensation schemes, misaligning their interests with the long-term interests of the firm. Complexity exacerbates this problem by increasing information asymmetry between technically sophisticated secondary managers and the senior managers to whom they report.

For example, with limited technical expertise and limited time available to devote to risk assessment, a firm's senior managers often want risk to be modeled and reduced to useable numbers. ${ }^{10}$ Models, however, can be manipulated. For example, VaR, or valueat-risk, has been the most widely used model for reducing investment risk to a number. ${ }^{11}$ As the VaR model became more accepted, banks began compensating analysts not only for generating profits but also for generating profits with low risks, measured by VaR. Analysts therefore began to refocus investment portfolios to concentrate more on securities (such as mortgage-backed securities and credit-defaults swaps) that generate gains but only rarely have losses. ${ }^{12}$ Because the likelihood of these losses was less than

10 Joe Nocera, Risk Mismanagement, N.Y. TiMES, Jan. 4, 2009, § 6 (Magazine), at 24. ${ }^{11} \mathrm{Id}$. at 26.

${ }^{12}$ Id. In a credit-default swap, one party (the credit "seller") agrees, in exchange for the payment to it of a fee by a second party (the credit "buyer"), to assume the credit risk of certain debt obligations of a specified borrower or other obligor. If a "credit event" (for example, default or bankruptcy) occurs in respect of that obligor, the credit seller will either (a) pay the credit buyer an amount calculated by reference to post-default value of the debt obligations or (b) buy the debt obligations (or other eligible debt obligations of the obligor) for their full face value from the credit buyer. See Steven L. Schwarcz, 
the risk percentages taken into account under $\mathrm{VaR}$ modeling-which typically excludes losses that have less than a one-percent (or, in some cases, five-percent) likelihood of occurring within the model's limited time frame-such losses were not included in the VaR computations. ${ }^{13}$ Analysts knew but did not always make clear to senior management that in the rare cases where such losses occurred, they would be huge. ${ }^{14}$

In theory, firms can solve this principal-agent failure by paying managers, including secondary managers, under longer-term compensation schemes-e.g., compensation subject to clawbacks or deferred compensation based on long-term results. In practice, however, that solution would confront a collective action problem: firms that offer their secondary managers longer-term compensation might not be able to hire as competitively as firms that offer more immediate compensation.

Regulation can solve the collective action problem, and thus correct the principalagent failure, by requiring financial firms_-or at least those that meet relevant criteria of materiality - to pay managers, including secondary managers, under longer-term compensation schemes. However, because good secondary managers can work in financial centers worldwide, international regulation may be needed to help fully solve the collective action problem.

4. Risk Marginalization. Risk dispersion is intended to reduce risk from the standpoint of any given investor through investment diversification and more efficient allocation of risk. But if risk is spread too widely, it can become marginalized such that rational market participants individually lack the incentive to monitor it and important correlations between risks can be obscured. ${ }^{15}$ Furthermore, because the human brain’s

Regulating Complexity in Financial Markets, 87 WASHINGTON UNIVERSITY LAW REVIEW 211, 235 n. 131 (2009/2010).

${ }^{13}$ Nocera, supra note 10 , at 46.

${ }^{14} \mathrm{Id}$.

${ }^{15}$ Steven L. Schwarcz, Marginalizing Risk, 89 WASH. U. L. REV. 487 (2012). 
ability to accurately correlate perceived and actual risk is limited, ${ }^{16}$ we tend to ignore or undervalue risk below a minimum threshold level. ${ }^{17}$ For these and other reasons, investors and other market participants sometimes underestimate and under-protect against risk, with few worrying about where dispersed risk goes or whether risk dispersion can impact the stability of financial markets. ${ }^{18}$

Marginalization of risk can have both microprudential and macroprudential consequences. The first—which is the subject of this Part II-occurs when the marginalization harms only the market participants (and their investors) that underestimate and under-protect against the risk. The second-which is the subject of Part III below (discussing macroprudential regulation)—occurs when the marginalization also harms the financial system itself, as happened in the financial crisis. ${ }^{19}$

Macroprudential consequences are especially likely to occur when marginalization of risk is coupled with collective action problems. For example, the benefits of exploiting finite capital resources might accrue to individual market participants, each of whom is motivated to maximize use of the resources, whereas the costs of exploitation may be distributed more widely. ${ }^{20}$ Absent regulatory intervention, market participants will individually pursue their self-interests to the detriment of other market participants (not to mention the financial system and the real economy). ${ }^{21}$ Moreover, market participants - especially those who are investors-may act as free

${ }^{16}$ See, e.g., Paul Slovic et al., Risk As Analysis and Risk As Feelings: Some Thoughts About Affect, Reason, Risk, and Rationality, 24 RisK ANALYSIS 311, 315 (2004).

17 See, e.g., Richard J. Herring et al., Wharton Fin. Inst. Ctr. and Oliver Wyman Inst. 12th Annual Fin. Risk Roundtable 2009: The New Role of Risk Management: Rebuilding the Model (June 24, 2009), available at http://knowledge.wharton.upenn.edu/article.cfm?articleid=2268. Cf. WILLIAM J. RAPAPORT ET AL., LANGUAGE AND MEANING IN COGNITIVE SCIENCE: COGNITIVE IsSUES AND SEMANTIC THEORY 85 (Josefa Toribio \& Andy Clark eds., 1998) (observing the human tendency to ignore details when overwhelmed by complexity).

${ }^{18}$ Marginalizing Risk, supra note 15.

${ }^{19} \mathrm{Id}$.

${ }^{20} \mathrm{Id}$.

${ }^{21}$ Id. 
riders, assuming that other investors have more significant amounts at stake and therefore must be engaging in due diligence and monitoring. ${ }^{22}$

Regulating risk dispersion that causes only microprudential consequences would likely be inefficient because market participants themselves should want to protect against those consequences. But regulating risk dispersion that causes macroprudential consequences could well be appropriate, and indeed, parallels the traditional regulatory focus of government. ${ }^{23}$

\section{B. Broader Regulatory Approaches.}

The discussion so far has addressed how microprudential regulation can mitigate market failures. Microprudential regulation can also address market failures more broadly by ensuring that firms can resist the adverse impact of market failures.

1. Capital Requirements. The most common way that regulation accomplishes this is by imposing "capital" requirements, which are intended to protect financial institutions against unexpected losses. Capital requirements in their modern form—based on ratios

${ }^{22}$ Id. Cf. Gordon De Brouwer, Hedge Funds in EMERging MARKETS 150 (2001) (noting that "even rational market participants may at times ignore their own private information and follow the actions of earlier participants because the [perceived] information in other people's collective actions overwhelms the individual's private information.”). More crassly, an investor may rationalize that it will be in no worse position than its competitors, who are making these same kinds of investments, if the investment fails—especially given the investment's relatively small size. Even if that rationalization is justified at the outset, however, continuing competitive pressures may motivate the investor to increase the investment, especially where approval of the initial investment sets an institutional precedent that makes further approvals easier. Marginalizing Risk, supra note 15.

${ }^{23}$ For a discussion of how to design that regulation, see id. (arguing that although regulatory responses may be second best, imperfect regulation may well be preferable to limiting risk dispersion because the latter could inadvertently increase the potential for regulatory arbitrage, increase financial instability, and impair the ability of parties to achieve negotiated market efficiencies). 
rather than fixed dollar amounts-were introduced into banking regulation in the 1980s. ${ }^{24}$ In that form, the requirements are expressed as capital-adequacy ratios: the minimum ratio of equity (including equity-like securities) that a bank must hold as a percentage of risk-weighted assets.

The imposition of capital requirements at the national level created a collective action problem: banks subject to those requirements might become less competitive, at least from a cost standpoint, than banks in nations that did not impose such requirements (or that imposed less strict requirements). In response, bank regulators around the world began to work together, through the Basel Committee on Banking Supervision (hereinafter, “BCBS”), ${ }^{25}$ to try to develop uniform capital requirements. ${ }^{26}$

In 1988, the BCBS released the Basel Capital Accord (hereinafter, "Basel I”), which set minimum capital-adequacy ratios for international banks in countries enacting Basel I into law. Over 100 countries enacted Basel I or at least principles based on Basel I. ${ }^{27}$

Basel I took a two-tiered approach to defining “capital.” Tier 1 capital included widely recognized forms of equity, such as shareholder's equity and retained earnings. Tier 2 included more controversial forms of equity, such as undisclosed reserves, assetrevaluation reserves, general loan-loss reserves, subordinated debt, and certain hybrid

${ }^{24}$ Douglas J. Elliott, Greg Feldberg, \& Andreas Lehnert, The History of Cyclical Macroprudential Policy in the United States, Fed. Reserve Bd., Finance and Economics Discussion Series No. 2013-29, at 34 (2013) (discussing how bank regulators switched from using capital requirements based on fixed dollar amounts to capital requirements based on the ratio of capital to total assets, and how the Basel I Accord spread that latter regulatory approach internationally).

${ }^{25}$ Established in 1974 by the central bank governors of the Group of Ten, the BCBS "provides a forum for regular cooperation on banking supervisory matters" and its objective is to "enhance understanding of key supervisory issues and improve the quality of banking supervision worldwide.” The BCBS has no formal authority; it leaves the implementation of recommendations to individual countries. See Basel Committee on Banking Supervision, http://www.bis.org/bcbs/ (last visited July 22, 2014).

${ }^{26}$ DANIEL K. TARULLO, BANKING ON BASEL 29 \& 45 (2008).

${ }^{27}$ Id. at 64-65. 
(debt/equity) capital instruments. Basel I required internationally active banks to maintain "total" capital—restricted to Tier 1 capital and a potentially discounted amount of Tier 2 capital $^{28}$ — equal to at least $8 \%$ of their risk-weighted assets. Assets-which in the case of banks are primarily loans payable to the banks-were risk-weighted according to five categories, depending on the generic type of the asset (and not, for example, the particular creditworthiness the borrower on a loan). ${ }^{29}$

Less than ten years after the release of Basel I, the BCBS began rethinking how to improve capital-adequacy ratios. Basel I's weaknesses included the bluntness of its riskweighting of assets and its exclusive focus on credit risk. ${ }^{30}$ Experience also showed that Basel I encouraged regulatory arbitrage, such as banks engaging in securitization transactions instead of making loans. ${ }^{31}$ The result was the release in 2004 of the Revised Basel Capital Accord (hereinafter, "Basel II”).

Basel II retained some elements of Basel I, including the definition of capital and the $8 \%$ requirement. However, it took a broader view of risk, including not only credit risk (the risk that a borrower will not repay its loan) but also market risk (the risk that the market value of an asset will decline) and operational risk (the "risk of loss resulting from inadequate or failed internal processes, people and systems or from external events"). ${ }^{32}$ Further, Basel II introduced a three-pillar regulatory structure, explained below, based on (1) minimum capital requirements, (2) supervisory review, and (3) market discipline.

\footnotetext{
${ }^{28}$ The amount of Tier 2 capital included in total capital could not exceed the amount of Tier 1 capital.

${ }^{29}$ TARULLO, supra note 26, at 57.

${ }^{30}$ Market risk was included in Basel I, however, under the 1996 Market Risk Amendment. Id. at 61.

${ }^{31}$ Capital Standards for Banks: The Evolving Basel Accord, BOARD OF GOVERNORS OF THE FEDERAL RESERVE SYSTEM 396 (Sept. 2003), http://www.federalreserve.gov/pubs/bulletin/2003/0903lead.pdf.

${ }^{32}$ Consultative Document Operational Risk, BASEl COMMITTEE ON BANKING SUPERVISION, CONSULTATIVE DOCUMENT OPERATIONAL RISK 2 (2001), available at http://www.bis.org/publ/bcbsca07.pdf. The goal of incorporating operational risk into the capital requirements was to reward banks with sophisticated risk management systems. Id. at 1-2.
} 
The first pillar-minimum capital requirements — addressed credit, market, and operational risk. Banks had to take all of these risks into account when calculating their minimum capital requirement. Unlike Basel I, however, Basel II gave banks the option of assessing credit risks through one of two internal ratings-based procedures or under a standardized approach using external credit rating agencies. ${ }^{33}$ The second pillarsupervisory review—set forth guidelines for how banks should engage in risk assessment, emphasizing monitoring, early intervention, and prompt remedial action to prevent the capital-adequacy ratio from slipping below the $8 \%$ minimum. ${ }^{34}$ The third pillar-market discipline-focused on requiring banks to formally disclose their risks to the marketplace, thereby providing other banks and market participants with information needed to negotiate contract terms that, effectively, should reward healthy banks and penalize risky banks. ${ }^{35}$

Basel II was “available for implementation” at the end of 2007, but countries’ implementation timelines varied widely. The European Union fully implemented Basel II within a year, whereas Botswana and Gambia planned on full implementation by $2015 .^{36}$ The financial crisis, however, soon highlighted the need for capital-adequacy ratios that are less vulnerable to human error and bias. ${ }^{37}$ The result is Basel III, ${ }^{38}$ which has been

33 TARULlO, supra note 26, at 124-25. Banks could use three different methods to calculate operational risk: the basic indicator approach, the standardized approach, and the advanced/internal measurement approach. Market risk should be determined by the value at risk approach.

${ }^{34}$ GeOfFrey P. Miller \& FABrizio CAFAGgi, The GOVERnANCE AND REgulation of INTERNATIONAL FINANCE 175-76 (2013).

${ }^{35}$ Pillar 3 disclosure requirements for remuneration, BASEL COMMITTEE ON BANKING SUPERVISION 1, (July 2011), http://www.bis.org/publ/bcbs197.pdf.

36 TARULLO, supra note 26, at 126-27; Basel II, 2.5, and III Implementation, FINANCIAL STABILITY INSTITUTE 4 \& 8 (July 2012), http://www.bis.org/fsi/fsiop2012.pdf.

${ }^{37}$ MiLler \& CAFAGGI, supra note 34, at 180-81.

38 "Basel III" collectively refers to "Basel III: A global regulatory framework for more resilient banks and banking systems," "Basel III: International framework for liquidity risk measurement, standards and monitoring," and "Annex: Minimum requirements to ensure loss absorbency at the point of non-viability." See Basel III: A global regulatory framework for more resilient banks and banking systems, BASEL COMMITTEE ON 
agreed to by members of the BCBS but is not slated for full implementation until January $2019 .{ }^{39}$

Basel III reforms Basel II, ${ }^{40}$ including by improving the inputs for banks' internal ratings-based (sometimes called "IRB") risk-assessment approaches. Basel III also more strictly defines what is included in Tier I capital ${ }^{41}$ and sets a minimum capital-adequacy requirement for Tier 1 capital itself (in addition to the minimum capital-adequacy requirement for total capital). ${ }^{42}$ Basel III also introduces greater disclosure requirements, a liquidity requirement, a leverage requirement, and two buffers—a $2.5 \%$ capital conservation buffer and a countercyclical capital buffer. The capital conservation buffer

BANKING SUPERVISION (Dec. 2010), http://www.bis.org/publ/bcbs189_dec2010.pdf [hereinafter, Basel III: A global regulatory framework]; Basel III: International framework for liquidity risk measurement, standards and monitoring, BASEL COMMITTEE ON BANKING SUPERVISION (Dec, 2010), http://www.bis.org/publ/bcbs188.pdf; Annex: Minimum requirements to ensure loss absorbency at the point of non-viability, BASEL COMMITTEE ON BANKING SUPERVISION (Jan. 2011), http://www.bis.org/press/p110113.pdf.

${ }^{39}$ The European Union and the United States enacted final sets of Basel III regulations in June and July of 2013. According to an August 2013 BCBS report, "internationally active banks continue to build capital, and appear well placed to meet the full set of fully phased-in minimum Basel III capital requirements ahead of the 2019 deadline.” Report to G20 Leaders on monitoring implementation of Basel III regulatory reforms, BASEL COMMITTEE ON BANKING SUPERVISION 1 (Aug. 2013), http://www.bis.org/publ/bcbs260.pdf.

${ }^{40}$ Basel III modifies and builds on existing Basel capital accords, including Basel II. International regulatory framework for banks (Basel III), BANK FOR INT'L SETTLEMENTS, http://www.bis.org/bcbs/basel3.htm (last visited Aug. 3, 2014).

41 "The concept of Tier 1 that we are familiar with will continue to exist and will include common equity and other instruments that have a loss-absorbing capacity on a "going concern" basis, for example certain preference shares. Innovative capital instruments which were permitted in limited amount as part of Tier 1 capital will no longer be permitted and those currently in existence will be phased out.” Hervé Hannoun, Gen. Manager, Bank for Int'l Settlements, The Basel III Capital Framework: a decisive breakthrough, BoJ-BIS High Level Seminar on Financial Regulatory Reform: Implications for Asia and the Pacific Hong Kong SAR (Nov. 22, 2010), available at http://www.bis.org/speeches/sp101125a.pdf.

${ }^{42}$ The total capital minimum remains at 8\%, but Basel III requires that "Common Equity Tier 1 must be at least $4.5 \%$ of risk-weighted assets at all times" and that "Tier 1 Capital must be at least $6.0 \%$ of risk-weighted assets at all times." Basel III: A global regulatory framework, supra note 38 at para. 49. 
is mandatory, intended to ensure that banks build up capital reserves that can be drawn down in periods of stress to avoid breaches of the capital requirement minimum. ${ }^{43}$ The countercyclical capital buffer is discretionary, allowing national regulators to require banks to maintain an additional $2.5 \%$ of capital during periods of high credit growth. ${ }^{44}$

As traditional bank lending contracted during the financial crisis, shadow banking expanded and filled part of the vacuum. ${ }^{45}$ In response, Basel III also imposes capital requirements on some shadow-banking activities. For example, it extends capital requirements to certain commitments to provide credit (loss protection) or liquidity (protection on the timing of payments, where ultimate losses are not expected). It also imposes capital requirements on short-term off-balance sheet commitments. ${ }^{46}$

2. Ring-Fencing. Another broad regulatory approach is ring-fencing, which can be understood as legally deconstructing a firm in order to more optimally reallocate and reduce risk. ${ }^{47}$ The deconstruction can occur in various ways: by separating risky assets from the firm; by preventing the firm itself from engaging in risky activities or investing in risky assets; or by protecting the firm from affiliate and bankruptcy risks.

\footnotetext{
${ }^{43}$ Basel III: A global regulatory framework, supra note 38, at para. 122.

${ }^{44}$ Id. at para. $18-22$.

${ }^{45}$ See supra notes 2-7 and accompanying text (discussing shadow banking).

${ }^{46}$ Daniel K. Tarullo, Governor, Governors of the Federal Reserve System, Speech at the Americans for Financial Reform and Economic Policy Institute Conference, Nov. 22, 2013, available at http://www.federalreserve.gov/newsevents/speech/tarullo20131122a.htm. In the United States, the Dodd-Frank Act imposes additional possible capital requirements. Section 171 of that Act, for example, requires regulators to establish minimum leverage and riskbased capital requirements for "banks, bank holding companies, and nonbank financial firms identified by the [Financial Stability Oversight Council] for enhanced Fed supervision.” James M. Pappenfus, Dodd-Frank and Basel III's knowledge problem, 36 HOUSE J. INT'L L. 253, 262 (2014) (emphasis added). See also Regulatory Capital Rules: Regulatory Capital, Implementation of Basel III, Minimum Regulatory Capital Ratios, Capital Adequacy, Transition Provisions, and Prompt Corrective Action, 77 Fed. Reg. 52,791 (proposed Aug. 30, 2012) (to be codified in scattered parts of 12 C.F.R.).

${ }^{47}$ Steven L. Schwarcz, Ring-Fencing, 87 SOUTHERN CALIFORNIA LAW REVIEW 69 (2013).
} 
Two forms of ring-fencing are commonly used for banks. One is to protect a bank from being taken advantage of by its affiliated firms - essentially preserving the business and assets of the ring-fenced bank. Regulation may require, for example, that transactions between a bank and its affiliates be arm's length. This is exemplified by Section 23A of the U.S. Federal Reserve Act and by the recommendations of the report of the UK Independent Commission on Banking (often called the "Vickers Report"). ${ }^{48}$ The Vickers Report recommends, for example, that interactions by UK retail banks with their affiliates must be at arm's length. ${ }^{49}$

Ring-fencing is also commonly used to limit a bank’s risky activities and investments. This use of ring-fencing had been the focus of the Glass-Steagall Act in the United States, ${ }^{50}$ and is currently exemplified by the Volcker Rule, ${ }^{51}$ as well as by the UK Financial Services (Banking Reform) Act of 2013 and the Liikanen Report. ${ }^{52}$ The Volcker Rule, for example, limits proprietary trading by banks, which was thought to be

48 INDEPENDENT COMMISSION ON BANKING, FINAL REPORT RECOMMENDATIONS (2011) (often called the "Vickers Report” after Sir John Vickers, the Commission's chair). 49 Id. at 12.

50 The Glass-Steagall Act ring-fenced deposit-taking banks by prohibiting them from engaging in the securities business, which was perceived as risky. The Glass-Steagall Act's ring-fencing was repealed in November 12, 1999 by the passage of the GrammLeach-Bliley Act of 1999. Ch. 89, 48 Stat. 162 (1933) (codified as amended in scattered sections of 12 U.S.C.). Glass-Steagall refers to sections 16, 20, 21, and 32 of the Banking Act of 1933. Section 16 was codified as 12 U.S.C. $\S 24$ (Seventh). Section 20 was codified as 12 U.S.C. §377. Section 21 was codified as 12 U.S.C. §378(a)(1). Section 32 was codified as 12 U.S.C. $\S 78$. Repealed by the Gramm-Leach-Bliley Act, the Financial Services Modernization Act of 1999, (Pub. L. 106-102, 113 Stat. 1338, enacted Nov. 12, 1999), available at http://www.gpo.gov/fdsys/pkg/PLAW-106publ102/html/PLAW106publ102.htm.

51 This rule is named after former Federal Reserve Chairman Paul Volcker - often cited as its principal designer. It is being codified pursuant to the Dodd-Frank Act, 12 U.S.C. $\S \S 619$ \& 1851.

52 The "Liikanen Report" was promulgated by a European Commission-appointed panel of experts, chaired by Bank of Finland governor Erkki Liikanen. Although the Liikanen Report does not refer to ring-fencing directly, it recommends that banks separate certain of their risky activities from deposit-taking. Final Report of the High-level Expert Group on Reforming the Structure of the EU Banking Sector, chaired by Erkki Liikanen (Oct. 2, 2012). 
a cause contributing to the financial crisis. ${ }^{53}$ As codified, proprietary trading is defined as "engaging as a principal for the trading account of [a bank] in any transaction to purchase or sell, or otherwise acquire or dispose of, any security, any derivative, any contract of sale of a commodity for future delivery, any option on any such ... [aforementioned] financial instrument." ${ }^{54}$ This definition, however, has been criticized as itself raising questions, and the Volcker Rule itself has been criticized as reducing the economic efficiency of banks that profited from proprietary trading. ${ }^{55}$

Another common use of ring-fencing is to protect a firm from becoming subject to liabilities and other risks associated with bankruptcy—usually called making the firm "bankruptcy remote." ${ }^{, 56}$ Although this use of ring-fencing is standard for securitization and covered bond transactions, it is not typically used in banking. ${ }^{57}$ The reason is path

\footnotetext{
${ }^{53}$ Section 4 of the UK Banking Reform Act similarly prohibits retail banks from "dealing in securities as a principal.” The United Kingdom is also considering imposing a ban on proprietary trading by affiliates of UK retail banks-presumably to make it less likely that such affiliates could fail, which might imperil the retail banks. See PARLIAMENTARY COMMISSION ON BANKING STANDARDS, PROPRIETARY TRADING, 2012-13, H.C. 1034, at 15-19.

${ }^{54} 12$ U.S.C. § 1851(h)(4).

${ }^{55}$ See, e.g., Charles Whitehead, The Volcker Rule And Evolving Financial Markets, 1 HARV. Bus. L. ReV. 39, 40 (2011). Other criticisms include the argument that the Volcker Rule is motivating proprietary traders to leave commercial banks for firms like hedge funds and investment banks. See, e.g., Deutsche Bank Loses Option Trader Saiers to Hedge Fund Alphabet Management, BLOOMBERG (July 15, 2010, 10:33 AM), http://www.bloomberg.com/news/2010-07-14/deutsche-bank-loses-option-trader-saiersto-hedge-fund-alphabet-management.html; Top JPMorgan Prop Trader Leaves To Launch Hedge Fund, FORBES (Feb., 15, 2013, 12:48 PM), http://www.forbes.com/sites/halahtouryalai/2013/02/15/top-jpmorgan-prop-trader-leavesto-launch-hedge-fund/. These firms are poorer at absorbing losses than commercial banks, which tend to have much larger equity cushions, thus shifting the risk of proprietary trading to a frailer part of the financial system.

${ }^{56}$ Steven L. Schwarcz, Securitization and Structured Finance, ELSEvIER's ENCYCLOPEDIA OF FINANCIAL GLOBALIZATION 6 (2011).

${ }^{57}$ Ring-fencing can also be used to help ensure that a firm is able to operate on a standalone basis even if its affiliated firms fail, but this form of ring-fencing has limited application to financial regulation. It is more commonly used by utility companies that need to ensure the public's uninterrupted access to an important public service. See RingFencing, supra note 47.
} 
dependent: at least in the United States, banks have not historically been subject to bankruptcy law. ${ }^{58}$

3. Monitoring Through Stress Testing. Another broader regulatory approach is stress testing, which is effectively a form of monitoring. ${ }^{59}$ Stress testing has long been used in diverse fields, including engineering and medicine, to gauge the stability of something through rigorous testing beyond normal operating conditions. In a banking context, stress testing examines how banks would be likely to fare under hypothetical negative economic conditions, including financial market crashes, high unemployment and high default rates, failures of other large financial institutions, and liquidity shortages. ${ }^{60}$

Although some banks have earlier used stress testing in their internal risk management, it has been required since 1996 by an amendment to Basel I. ${ }^{61}$ Since the financial crisis, regulators have expanded the use of stress testing. ${ }^{62}$ In the United States,

\footnotetext{
${ }^{58}$ See 11 U.S.C. § 109 (excluding deposit-taking banks and domestic insurance companies from federal bankruptcy law).

${ }^{59}$ See infra notes 63-64 and accompanying text. This contrasts with the other regulation discussed, which is intended to correct market failures.

${ }^{60}$ Robert Weber, A Theory for Deliberation-Oriented Stress Testing Regulation, 98 MinN. L. REV. 2236, 2239 (2014).

${ }^{61}$ Mario Quagliariello, StRess-testing the Banking System: Methodologies AND APPLICATIONS 1 (2009); Amendment to the Capital Accord to incorporate market risks, Basel Committee on Banking Supervision 42 (originally released Jan. 1996, last updated Nov. 2005), http://www.bis.org/publ/bcbs119.pdf.

${ }^{62}$ Notably, this was sparked by the 2009 stress tests performed by the U.S. Federal Reserve on nineteen of the country's largest banks in an attempt to stave off future losses and ensure that those banks could continue lending despite the deepening recession. See Timothy Geithner, How We Tested the Big Banks, N.Y. TimEs, May 7, 2009, at A33, available at http://www.nytimes.com/2009/05/07/opinion/07geithner.html?_r=0 (explaining the motivation of the stress testing program was to "help replace uncertainty with transparency" as well as outlining the stress testing process).
} 
for example, the Dodd-Frank Act requires stress testing not only for banks but also for non-bank systematically important financial institutions. ${ }^{63}$

Stress testing is a form of monitoring because it gauges the health of financial institutions but does not directly offer a remedy should those institutions that fail the test. In the event a bank fails a stress test, regulators must decide on the next steps. The European Central Bank, for example, has been conducting stress tests on EU banks; a bank that fails the test will have two weeks to submit its proposed corrective measures and capital plans. ${ }^{64}$

\section{MACROPRUDENTIAL REGULATION}

Macroprudential regulation refers to financial regulation of the financial system's ability to function as a network, within which firms and markets can operate. As discussed, its primary goal is to prevent systemic risk. Ideal macroprudential regulation would therefore act ex ante, limiting the triggers of systemic shocks.

\section{A. Limiting the Triggers of Systemic Shocks.}

1. Maturity Transformation. Several vulnerabilities of the financial system can trigger systemic shocks. The classic vulnerability is maturity transformation: the assetliability mismatch that results from the short-term funding of long-term projects. This mismatch creates a "liquidity default risk" that borrowers will be unable to repay their lenders. According to some scholars, illiquidity is the fundamental source of financial failure.

\footnotetext{
${ }^{63}$ Weber, supra note 60 , at 2292. Banks with more than $\$ 10$ billion (previously the threshold was $\$ 50$ billion) in assets are now required to have two stress tests performed annually, one done internally and one conducted by regulators.

64 Jeff Black \& Sonia Sirletti, ECB Plans to Limit Stress-Test Inputs in Bank Checks, BlOOMBERG (July 11, 2014, 11:09 AM), http://www.bloomberg.com/news/2014-07-11/ecb-plans-to-limit-stress-test-inputs-inbank-checks.html (describing the European Central Bank's plan to conduct stress tests of euro-area lenders).
} 
A bank "run” is the typical (though far from the only) example of maturity transformation leading to a liquidity default. In a bank run, panicked depositors will collectively demand their money. If, as is usual, the long-term maturities of the bank's assets cannot generate cash quickly enough to pay the current depositor demands, the bank will default. And if (again, as is usual) the defaulting bank is interconnected with other banks, the defaulting bank's failure to pay its obligations to those other banks can, in turn, deprive those other banks of money to pay their creditors-with the chain spreading. Maturity transformation was also at the core of the financial crisis, such as the well-known shadow-banking example, discussed below, of money-market mutual funds that used short-term loans by investors, essentially withdrawable on demand, to fund long-term projects.

In mid-September 2008, a money-market mutual fund in the United States "broke the buck" for the first time in fourteen years. ${ }^{65}$ This meant that the fund's price per share, or net asset value ("NAV”), fell below $\$ 1.00$ — the point at which fund investors will begin losing money. Because shares in mutual funds were not then U.S. government insured, ${ }^{66}$ fund investors industrywide raced to try to withdraw their investments from any remaining short-term assets - the effective equivalent of a bank run-before other investors depleted those assets. ${ }^{67}$ To mitigate potential systemic consequences, the U.S. government stepped in to guarantee money-market mutual fund share prices, thereby calming investors and quelling the run. ${ }^{68}$

\footnotetext{
${ }^{65}$ Christopher Condon, Reserve Primary Money Fund Falls Below \$1 a Share, BLOOMBERG (Sept. 16, 2008, 9:41 PM), http://www.bloomberg.com/apps/news?pid=newsarchive\&sid=a5O2y1go1GRU. See supra note 4 and accompanying text for a discussion of money-market mutual funds. See also infra note 79 and accompanying text for discussion of proposed regulatory solutions. 66 This contrasts with bank deposits, which are guaranteed up to specified limits by the U.S. Federal Deposit Insurance Corporation.

${ }^{67}$ Jeffrey N. Gordon \& Christopher M. Gandia, Money Market Funds Run Risk: Will Floating Net Asset Value Fix the Problem?, 2014 Colum. Bus. L. REV. 313, 317 (2014) (also noting that the money-market mutual funds were unable to secure short-term credit to meet the sudden demand).

${ }^{68}$ Id.
} 
Maturity transformation is thus a vulnerability of the financial system, but it is also a benefit. Using short-term debt to fund long-term projects is attractive because, if managed to avoid a default, it tends to lower the cost of borrowing. The interest rate on short-term debt is usually lower than that on long-term debt because, other things being equal, it is easier to assess a borrower's ability to repay in the short term than in the long term, and long-term debt carries greater interest-rate risk.

Regulation should not, therefore, attempt to prohibit maturity transformation per se. In a banking context, for example, the standard regulatory solution is not to require banks to match-fund their assets. Rather, governments often provide deposit insurance that limits the likelihood that depositors will panic. ${ }^{69}$

In other contexts, however, maturity transformation may well remain a real vulnerability. Because many shadow-banking sources of funding, such as short-term commercial paper, are not payable on demand-and thus are not subject to the same type of "run” risk as traditional deposits_- deposit insurance is not a solution. And other regulatory solutions are likely to be imperfect. ${ }^{70}$ Depending on how it is designed, regulation protecting the financial system against maturity-transformation risk can increase moral hazard, which in turn can motivate risky actions by shadow banks. For example, regulation that protects the shadow-bank issuer of short-term securities against its own risky actions would almost certainly increase moral hazard. Regulation that limits incentives for shadow banks to engage in maturity transformation-such as imposing higher capital requirements on firms that engage in maturity transformation-

69 See supra notes 66-68 and accompanying text.

${ }^{70}$ In the context of money-market mutual funds, for example, regulators have been debating potential reforms for years. In July 2014, the U.S. Securities and Exchange Commission ("SEC”) announced regulatory reforms to be implemented in two years, but the regulation remains controversial. See Sarah N. Lynch, SEC's long path to money market fund reform ends in compromise, REUTERS (July 23, 2014, 5:16 PM), http://www.reuters.com/article/2014/07/23/us-sec-moneyfundsidUSKBN0FS08E20140723. See also supra notes 3, 6, \& 65-68 and accompanying text for a discussion of money-market mutual funds and shadow banking. 
would reduce moral hazard but would also reduce the economic efficiency achieved by maturity transformation. ${ }^{71}$

Thus, the liquidity default risk that inevitably remains can trigger systemic shocks. Indeed, the failure of pre-financial-crisis regulation to adequately address liquidity default risk resulting from shadow banking's maturity transformation "is widely believed to have contributed to the buildup of risks in the financial system in the period leading up to" that crisis. ${ }^{72}$

2. Limited Liability. Another vulnerability is the financial system's failure to require market participants to fully internalize their harm. As a result, they are economically motivated to engage in risky but profitable transactions because much of the harm from a possible systemic collapse would be externalized onto other market participants as well as onto ordinary citizens impacted by an economic collapse.

The most direct regulatory solution should therefore be to require market participants to internalize that harm. For various reasons, including the longstanding limited liability accorded corporate shareholders throughout the world, that may not be feasible. With the rise of shadow banking, limited liability is becoming especially problematic. For the small and decentralized firms (such as hedge funds) that dominate the shadow-banking sector, equity investors tend to be active managers. Limited liability gives these investor-managers strong incentives to take risks that could generate out-size personal profits, even if that greatly increases systemic risk.

\footnotetext{
${ }^{71}$ A possible compromise might be regulation that protects not individual shadow banks but the overall markets for short-term securities, such as the Commercial Paper Funding Facility put into place by the U.S. Federal Reserve during the financial crisis to protect the commercial paper market. I later discuss this in Part III.C.2, infra.

${ }^{72}$ Regulating Ex Post, supra note 7, at 85.
} 
3. Other Vulnerabilities. The very nature of the financial system also subjects it to other systemic vulnerabilities that cannot be regulated away. ${ }^{73}$ Because the financial system exhibits the characteristics of — and effectively comprises—a high-risk system that is susceptible to "normal accidents," regulators cannot predict, and therefore cannot eliminate, all the triggers of systemic shocks. Another reason why regulators cannot realistically eliminate all of the triggers of systemic shocks is that certain of the market failures that are the subject of imperfect microprudential regulation could even trigger systemic failures. For example, information failure, rationality failure, agency failure, and risk marginalization could, individually or in combination, cause one or more large financial firms to overinvest, leading to bankruptcy; and the bankruptcy of a large, interconnected financial firm could lead to a systemic collapse. It therefore is virtually certain that the financial system will face systemic shocks from time to time.

\section{B. Existing Macroprudential Regulatory Approaches.}

Since the financial crisis, policymakers and regulators generally recognize the need for macroprudential regulation. However, they tend to approach it as constituting a loose assortment of “tools” in their "toolkit.” The macroprudential 'toolkit' generally comprises cross-sectoral leverage ceilings, credit and credit-growth ceilings, reserve and capital buffer requirements, liquidity minima and maturity mismatch maxima, dynamic countercyclical provisioning, and surveillance and data collection. ${ }^{74}$ It is still unclear, though, which "tools" should be used in which circumstances, or as to how the tools should be calibrated. That itself creates risk because the misapplication of these toolssuch as imposing excessively restrictive leverage or credit and credit-growth ceilingsmay be as likely to cause financial problems as to solve them.

\footnotetext{
${ }^{73}$ Cf. supra notes 19-23 and accompanying text (observing that marginalization of risk can also have macroprudential consequences, and that regulatory solutions are all second best).

${ }^{74}$ Robert Hockett, “Implementing Macroprudential Finance-Oversight Policy: Legal Considerations” 12-13 (Jan. 20, 2013 draft prepared for the International Monetary Fund; on file with author).
} 
For example, because economic growth is strongly tied to the availability of credit, ${ }^{75}$ overly restrictive credit or credit-growth ceilings could cause the economy to contract. Yet the very justification for these ceilings- the "compelling evidence that

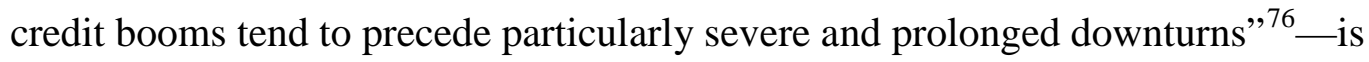
questionable. Evidence of the mere tendency for credit booms to precede severe economic downturns does not prove a causal relationship. And even if that causal relationship were proved, the evidence does not yet appear to provide a clear basis for quantifying a limitation on credit growth.

The misapplication of capital requirements could also backfire. The regulatory reform dialogue increasingly is focusing on a countercyclical and flexible approach to capital requirements. ${ }^{77}$ Finance, and especially banking, is by nature procyclical: the increased availability of capital stimulates economic growth. ${ }^{78}$ Historically, financial regulation has tended to be procyclical as well—loosening during booms and becoming stricter after crises. ${ }^{79}$ The rationale for countercyclical capital requirements is that they

${ }^{75}$ See, e.g., GEORGE COOPER, THE ORIGIN OF FINANCIAL CRISES: CENTRAL BANKS, CREDIT BUBBLES, AND THE EFFICIENT MARKET 121 (2008).

${ }^{76}$ Elliott, Feldberg, \& Lehnert, supra note 24, at 2 (observing this justification for the "growing support for the view that policymakers should use a variety of tools to minimize ... excessive credit growth" that could fuel asset bubbles). They also observe, id., that some economists even conclude from this evidence that the "primary purpose" of macroprudential tools should be "controlling credit growth."

${ }^{77}$ See Kristin N. Johnson, Macroprudential Regulation: A Sustainable Approach to Regulating Financial Markets, 2013 University of ILLINOIS LAW REVIEW 881, 916 (2013) (discussing flexible capital requirements as a macroprudential tool); Richard Berner, Director of Office of Financial Research, Remarks at the Joint Conference of the Federal Reserve Bank of Cleveland and Office of Financial Research, Financial Stability Analysis: "Using the Tools, Finding the Data” (May 30, 2013) (identifying countercyclical capital requirements as a tool to reduce or neutralize "threats to financial stability”).

${ }^{78}$ Haocong Ren, Countercyclical Financial Regulation 3 (The World Bank, Working Paper No. 5823, 2011), available at http://elibrary.worldbank.org/doi/pdf/10.1596/18139450-5823 (also observing that during economic booms and bubbles, credit expansion outpaces economic growth; and that during economic downturns, lending contracts, further worsening economic prospects).

${ }^{79}$ Brett H. McDonnell, Designing Countercyclical Capital Buffers, 18 N.C. BANKING INST. 123 (2013) (noting that the same factors that cause cycles in the financial markets, 
would help to moderate economic growth, discouraging the buildup of imbalances during economic booms and bubbles (by reducing excessive risk-taking and credit expansion). ${ }^{80}$

But countercyclical capital requirements are only as good as the accuracy of the indicators that determine their application and timing. Potential indicators include GDP growth, credit conditions, asset prices, banking performance and soundness indicators, leverage ratios, and credit and liquidity spreads. ${ }^{81}$ There has been debate, however, about whether countercyclical regulation is actually feasible given that it is virtually impossible to know ex ante whether a financial cycle is rational or merely a bubble. ${ }^{82}$ Furthermore, countercyclical regulation's effectiveness could be undermined by regulatory arbitrage if the measures are not analogously applied to relevant shadow banking activities. ${ }^{83}$

Accuracy is critical because the misapplication or mistiming of countercyclical regulation can have unintended adverse consequences, as illustrated by the notorious savings and loan ("S\&L”) crisis of the 1980s in the United States. S\&L institutions faced a period in which rising interest rates made lending less attractive to borrowers. ${ }^{84}$ To avoid having to commit government funds to bail out financially stressed institutions, regulators relieved the stress by engaging in a type of countercyclicality: they eased the capital ratios in order to "help banks muddle through [that] difficult period." 85 However, the result of that forbearance, in conjunction with other regulatory-relief steps, was to rapidly expand the size of the S\&L industry_from \$686 billion in 1982 to \$1.1 trillion

cause financial regulations to reinforce the cycles). See also id. (discussing how capital requirements are procyclical when they force banks to cut back on lending due to faltering capital positions because of decreasing credit quality and increasing losses, further deteriorating economic performance and resulting in even more credit losses).

${ }^{80}$ Ren, supra note 78, at 4-5.

${ }^{81}$ Ren, supra note 78 , at 6.

82 Professor Patricia A. McCoy, Lecture on Countercyclical Regulation and its Challenges at the Centre for Commercial Law Studies (June 26, 2013) (arguing that even for real estate bubbles, no one has adequate information ex ante to know for sure whether the price increases are rationale or merely a bubble).

83 Ren, supra note 78 , at 8.

${ }^{84}$ Elliott, Feldberg, \& Lehnert, supra note 24, at 34.

${ }^{85} \mathrm{Id}$. (observing that this countercyclicality was imprecisely implemented). 
$1985 .{ }^{86}$ When the S\&L industry eventually collapsed, its increased size led to the largest federal bailout in U.S. history up to that time. ${ }^{87}$

\section{Alternative Macroprudential Regulatory Approaches.}

It therefore is clear that, notwithstanding the best efforts of regulators, the financial system will inevitably face systemic shocks. Accordingly, macroprudential regulation should also work ex post—after a systemic shock is triggered — to break the transmission of the shock and limit its impact. This approach accords with chaos theory, which addresses the problem of inevitable systemic shocks in complex engineering systems. The most successful (complex) systems are those in which the consequences of failures are limited.

1. Breaking the Transmission of Systemic Shocks. In examining how macroprudential regulation could break the transmission of systemic shocks and limit their impact, consider three factors that the International Monetary Fund (IMF) and the international Financial Stability Board (FSB) have identified as determinants of systemic risk: interconnectedness, size, and substitutability. In reality, these factors relate not to vulnerability but to the transmission of systemic shocks and their impact. These factors implicitly assume that the financial system is subject to vulnerabilities that could trigger systemic shocks.

To break the transmission of systemic failures in the financial system would require that the transmission mechanisms all be identifiable. It is probably not feasible, however, to identify all those mechanisms in advance. Ring-fencing can be useful as a

\footnotetext{
${ }^{86} I d$. The eased capital ratios enabled rapid growth. For example, a \$2 million dollar investment in a new S\&L could be leveraged into $\$ 1.3$ billion in assets. See 1 DIV. OF Research And Statistics, Fed. Deposit Ins. CORP., History Of The 80’S-Lessons FOR THE FUTURE, 172-3 (1997), available at http://www.fdic.gov/bank/historical/history/index.html. ${ }^{87}$ See Lawrence A. Cunningham \& David Zaring, Three or Four Approaches to Financial Regulation: A Cautionary Analysis Against Exuberance in Crisis Response, 78 GEORGE WASHington LAW REVIEW 39, 51 (2009).
} 
crude barrier, however. ${ }^{88}$ This is the primary regulatory approach taken in the United Kingdom, for example, to protect so-called retail banking, such as basic lending and deposit taking. ${ }^{89}$

2. Stabilizing Systemically Important Firms and Markets. Because regulation cannot completely break the transmission of systemic shocks, regulators must also focus on trying to stabilize systemically important firms and financial markets impacted by the shocks. There are at least two ways that regulation could accomplish that: by requiring those firms and markets to be more internally robust, and/or by providing appropriate liquidity to those firms and markets.

Regulation could help to stabilize systemically important firms and markets by requiring them to be more internally robust. Financial regulation has long focused on requiring traditional deposit-taking banks to be robust, usually through capital and solvency requirements. Since the financial crisis, the United States, the European Union, and other jurisdictions are beginning to also subject "systemically important” non-bank financial firms (“SIFI”s) to a range of capital, solvency, and similar requirements.

This approach is imperfect, however, because it mixes the goals of macroprudential and microprudential regulation. The microprudential goal is to assure that individual firms can continue operating. By subjecting banks and SIFIs to rigorous capital, solvency, and similar requirements (to assure that they can continue operating), that microprudential goal inadvertently becomes a goal of the macroprudential regulation. The flaw in this mixed approach is that macroprudential regulation's only goal should be to protect the financial system's overall capacity to function as a network. Macroprudential regulation need not, therefore, impose capital or solvency requirements on individual firms - even those that are systemically important—so long as it otherwise

\footnotetext{
${ }^{88}$ See supra notes 47-58 and accompanying text (discussing ring-fencing).

${ }^{89}$ See supra note 53 and accompanying text.
} 
achieves that goal. This regulatory flexibility is important because capital and solvency requirements do not always efficiently reduce systemic risk. ${ }^{90}$

Other potential approaches to make systemically important firms more internally robust include requiring at least some portion of the firm's debt to be in the form of socalled contingent capital. Contingent capital debt would automatically convert to equity upon the occurrence of pre-agreed events.

As a parallel to stabilizing systemically important firms by requiring them to be more internally robust, regulation could help to stabilize systemically important financial markets by requiring them also to be more internally robust. For example, increased speed in data transmission is generally associated with market efficiency, but the extreme speeds at which algorithmic trading takes place creates a danger of market collapse. In response, securities market regulators have been proposing the adoption of circuitbreaker rules to at least temporarily halt trading under specified circumstances.

Regulation could also help to stabilize systemically important firms and markets by providing appropriate liquidity. Liquidity has traditionally been used, especially by government central banks acting as lenders of last resort, to help prevent financial firms from defaulting. Ensuring liquidity to stabilize systemically important firms could follow this pattern, except that the source of the liquidity could at least be partly privatized by taxing those firms to create a systemic risk fund.

\footnotetext{
${ }^{90}$ Regulating Financial Change, supra note 1. Cf. Katharina Pistor, "On the Theoretical Foundations for Regulating Financial Markets” 46 (June 2012 draft, available at http://works.bepress.com/katharina_pistor/11) (observing that "imposing capital or reserve requirements can push market participants to find ways [including the use of derivatives] to formally comply while making sure that their disposable assets are in fact not much curtailed," thereby creating "additional sources of liquidity risk [that can] remain[] largely unrecognized by financial intermediaries and regulators alike"). This chapter does not address derivatives per se, because they will be addressed elsewhere in the Handbook. For a brief introduction to derivatives and financial regulation, see Steven L. Schwarcz, Derivatives and Collateral: Balancing Remedies and Systemic Risk, UNIVERSITY OF ILLINOIS LAW REVIEW symposium issue (forthcoming 2014-15), available at http://ssrn.com/abstract=2419460.
} 
Privatizing the source of liquidity would likewise help to internalize externalities, thereby not only offsetting the cost to taxpayers of liquidity advances that are not repaid but also, if structured appropriately, reducing moral hazard by discouraging fund contributors-including those that believe they are "too big to fail"-from engaging in financially risky activities. $^{91}$

Because financial markets can also be triggers and transmitters of systemic shocks, liquidity should be used to stabilize systemically important financial markets. For example, in response to the post-Lehman collapse of the commercial paper market, the U.S. Federal Reserve created the Commercial Paper Funding Facility (“CPFF”) to act as a lender of last resort for that market, with the goal of addressing "temporary liquidity distortions" by purchasing commercial paper from highly rated issuers that could not otherwise sell their paper. The CPFF helped to stabilize the commercial paper market.

\section{CONCLUSION}

Banking and financial regulation is needed to protect the financial system, which provides functions that are essential to economic development. Traditionally, financial regulation focused on banking because banks historically have aggregated moneys (primarily by taking deposits from customers) and then allocated those monies (by making loans to borrowers). Traditional financial regulation is geared to ensuring that deposit-taking banks can continue to perform these functions efficiently. In recent years, however, shadow banking has begun to overtake traditional banking. Financial regulation must therefore also address shadow banking.

Regardless of whether it addresses traditional or shadow banking, financial regulation has two overall goals: to ensure that the components of the financial system-

\footnotetext{
${ }^{91}$ For a thoughtful perspective on banks getting too big to manage, see Lawrence G. Baxter, Betting Big: Value, Caution and Accountability in an Era of Ultra Large Banking, 31 REV. BANK’G \& FIN. L. 765, 879 (2012).
} 
firms and markets—can efficiently perform their underlying economic functions, and to ensure the financial system's ability to itself function as a network within which those components can operate. Regarding the first goal, firms and markets generally operate efficiently absent market failures. Financial regulation thus should help to correct those market failures - which include information and rationality failure, which can undermine the reliability of pricing, and agency failure in which conflicts can distort decisionmaking.

The other goal of financial regulation is to protect against the risk-usually called systemic risk - that the financial system will fail to function as a network within which firms and markets can operate. Although this regulation ideally would prevent systemic risk, several vulnerabilities of the financial system (such as maturity transformation and limited corporate liability) can trigger systemic shocks. It therefore is virtually certain, notwithstanding the best efforts of regulators, that the financial system will face systemic shocks from time to time. Accordingly, financial regulation should also be designed to work after systemic shocks are triggered, by breaking the transmission of the shocks and limiting their impact.

\section{BIBLIOGRAPHY}

11 U.S.C. $\S 109$.

12 U.S.C. $\S 1851(\mathrm{~h})(4)$.

Amendment to the Capital Accord to incorporate market risks, Basel Committee on Banking Supervision 42 (originally released Jan. 1996, last updated Nov. 2005), http://www.bis.org/publ/bcbs119.pdf.

Iman Anabtawi,

Regulating Ex Post: How Law Can Address the Inevitability of Financial Failure, 92 Texas Law Review 75 (2013) (with Steven L. Schwarcz). 
Annex: Minimum requirements to ensure loss absorbency at the point of non-viability, BASEL COMMITTEE ON BANKING SUPERVISION (Jan. 2011), http://www.bis.org/press/p110113.pdf.

Basel II, 2.5, and III Implementation, FinANCIAL STABILITY INSTITUTE 4 \& 8 (July 2012), http://www.bis.org/fsi/fsiop2012.pdf.

Basel III: A global regulatory framework for more resilient banks and banking systems, BASEL COMMITTEE ON BANKING SuPERVISION (Dec. 2010), http://www.bis.org/publ/bcbs189_dec2010.pdf.

Basel III: International framework for liquidity risk measurement, standards and monitoring, BASEL COMMITTEE ON BANKING SUPERVISION (Dec, 2010), http://www.bis.org/publ/bcbs188.pdf.

Basel Committee on Banking Supervision, http://www.bis.org/bcbs/ (last visited July 22, 2014).

Lawrence G. Baxter, Betting Big: Value, Caution and Accountability in an Era of Ultra Large Banking, 31 REV. BANK’G \& FIN. L. 765 (2012).

Ben S. Bernanke, Chairman, Speech at the Russell Sage Foundation and The Century Foundation Conference on Rethinking Finance (April 13, 2012), available at http://www.federalreserve.gov/newsevents/speech/bernanke20120413a.htm.

Richard Berner, Director of Office of Financial Research, Remarks at the Joint Conference of the Federal Reserve Bank of Cleveland and Office of Financial Research, Financial Stability Analysis: "Using the Tools, Finding the Data” (May 30, 2013).

Jeff Black \& Sonia Sirletti, ECB Plans to Limit Stress-Test Inputs in Bank Checks, BLOOMBERG (July 11, 2014, 11:09 AM), http://www.bloomberg.com/news/2014-07-11/ecb-plans-to-limit-stress-test-inputs-inbank-checks.html.

Gordon De Brouwer, HEDGE FundS IN EMERGING MARKETS 150 (2001).

Capital Standards for Banks: The Evolving Basel Accord, BOARD OF GOVERNORS OF THE FEDERAL RESERVE SYSTEM 396 (Sept. 2003), http://www.federalreserve.gov/pubs/bulletin/2003/0903lead.pdf.

Christopher Condon, 
Reserve Primary Money Fund Falls Below \$1 a Share, BLOOMBERG (Sept. 16, 2008, 9:41 PM),

http://www.bloomberg.com/apps/news?pid=newsarchive\&sid=a5O2y1go1GRU.

Consultative Document Operational Risk, BASEL COMMITTEE ON BANKING SUPERVISION, CONSULTATIVE DOCUMENT OPERATIONAL RISK 2 (2001), available at http://www.bis.org/publ/bcbsca07.pdf.

GEORGE COOPER, The Origin of FinANCial CRises: Central Banks, Credit BubBles, AND the EFFICIENT MARKET 121 (2008).

Lawrence A. Cunningham \& David Zaring, Three or Four Approaches to Financial Regulation: A Cautionary Analysis Against Exuberance in Crisis Response, 78 GEORGE WASHINGTON LAW REVIEW 39, 51 (2009).

Yuliya Demyanyk \& Elena Loutskina, Mortgage Companies and Regulatory Arbitrage 2 (Fed. Res. Bank of Cleveland, Working Paper No. 12-20R 2014), available at http://www.clevelandfed.org/research/workpaper/2012/wp1220r.pdf.

Div. Of Research And Statistics, Fed. Deposit Ins. Corp., History Of THE 80’S-Lessons For THE Future, 172-3 (1997), available at http://www.fdic.gov/bank/historical/history/index.html.

Dodd-Frank Act, 12 U.S.C. §§ 619 \& 1851.

Douglas J. Elliott, Greg Feldberg, \& Andreas Lehnert, The History of Cyclical Macroprudential Policy in the United States, Fed. Reserve Bd., Finance and Economics Discussion Series No. 2013-29, at 34 (2013).

FIN. STABILITY BD., GLOBAL SHADOW BANKING MONITORING REPORT (2012), http://www.financialstabilityboard.org/publications/r_121118c.pdf.

Final Report of the High-level Expert Group on Reforming the Structure of the EU Banking Sector, chaired by Erkki Liikanen (Oct. 2, 2012).

Timothy Geithner, How We Tested the Big Banks, N.Y. TIMES, May 7, 2009, at A33, available at http://www.nytimes.com/2009/05/07/opinion/07geithner.html?_r=0.

Glass-Steagall refers to sections 16, 20, 21, and 32 of the Banking Act of 1933. Section 16 was codified as 12 U.S.C. § 24 (Seventh). Section 20 was codified as 12 U.S.C. §377. Section 21 was codified as 12 U.S.C. §378(a)(1). Section 32 was codified as 12 U.S.C. 
Jeffrey N. Gordon \& Christopher M. Gandia, Money Market Funds Run Risk: Will Floating Net Asset Value Fix the Problem?, 2014 Colum. Bus. L. REV. 313, 317 (2014).

Gramm-Leach-Bliley Act, the Financial Services Modernization Act of 1999, (Pub. L. 106-102, 113 Stat. 1338, enacted Nov. 12, 1999), available at http://www.gpo.gov/fdsys/pkg/PLAW-106publ102/html/PLAW-106publ102.htm.

Philipp Halstrick, Tighter Bank Rules Give Fillip to Shadow Banks, REUTERS (Dec. 20, 2011, 4:17 AM), http://www.reuters.com/article/2011/12/20/ uk-regulation-shadow-bankingidUSLNE7BJ00T20111220 (last visited June 10, 2013).

Hervé Hannoun, Gen. Manager, Bank for Int'l Settlements, The Basel III Capital Framework: a decisive breakthrough, BoJ-BIS High Level Seminar on Financial Regulatory Reform:

Implications for Asia and the Pacific Hong Kong SAR (Nov. 22, 2010), available at http://www.bis.org/speeches/sp101125a.pdf.

Richard J. Herring et al., Wharton Fin. Inst. Ctr. and Oliver Wyman Inst. 12th Annual Fin. Risk Roundtable 2009: The New Role of Risk Management: Rebuilding the Model (June 24, 2009), available at http://knowledge. wharton.upenn.edu/article.cfm?articleid=2268.

Robert Hockett, “Implementing Macroprudential Finance-Oversight Policy: Legal Considerations” 12-13 (Jan. 20, 2013 draft prepared for the International Monetary Fund; on file with author).

International regulatory framework for banks (Basel III), BANK FOR INT’L SETTLEMENTS, http://www.bis.org/bcbs/basel3.htm (last visited Aug. 3, 2014).

INDEPENDENT COMMISSION ON BANKING, FINAL REPORT RECOMMENDATIONS (2011).

Kristin N. Johnson, Macroprudential Regulation: A Sustainable Approach to Regulating Financial Markets, 2013 University of ILLINOIS LAW REVIEW 881, 916 (2013).

Jeff Kearns, Deutsche Bank Loses Option Trader Saiers to Hedge Fund Alphabet Management, BLOOMBERG (July 15, 2010, 10:33 AM), http://www.bloomberg.com/news/2010-0714/deutsche-bank-loses-option-trader-saiers-to-hedge-fund-alphabet-management.html.

Timothy Lane, Deputy Governor of the Bank of Canada, "Shedding Light on Shadow Banking," Speech to the CFA Society (June 26, 2013), available at http://www.bis.org/review/r130628g.pdf. 
Sarah N. Lynch,

SEC's long path to money market fund reform ends in compromise, REUTERS (July 23, 2014, 5:16 PM), http://www.reuters.com/article/2014/07/23/us-sec-moneyfundsidUSKBN0FS08E20140723.

Jonathan Macey, Reducing Systemic Risk: The Role of Money Market Mutual Funds as Substitutes for Federally Insured Bank Deposits, 17 StAN. J.L. Bus. \& Fin. 131, 138 (2011).

Patricia A. McCoy, Professor, Lecture on Countercyclical Regulation and its Challenges at the Centre for Commercial Law Studies (June 26, 2013).

Brett H. McDonnell, Designing Countercyclical Capital Buffers, 18 N.C. BANKING INST. 123 (2013).

Geoffrey Miller \& Fabrizio Cafaggi,

The GOVERnANCE AND REgUlation of InTERnATIONAL FinANCE 175-76 (2013).

Joe Nocera,

Risk Mismanagement, N.Y. TIMES, Jan. 4, 2009, § 6 (Magazine), at 24.

James M. Pappenfus, Dodd-Frank and Basel III’s knowledge problem, 36 HousE J. INT’L L. 253, 262 (2014).

PARLIAMENTARY COMMISSION ON BANKING StANDARds, PROPRIETARY TRADING, 201213, H.C. 1034, at 15-19.

Pillar 3 disclosure requirements for remuneration, BASEL COMMITTEE ON BANKING SUPERVISION 1, (July 2011), http://www.bis.org/publ/bcbs197.pdf.

Katharina Pistor, “On the Theoretical Foundations for Regulating Financial Markets” 46 (June 2012 draft, available at http://works.bepress.com/katharina_pistor/11).

Sheridan Prasso, Shadow Banking, BlOOMBERG (Apr. 16, 2014), http://www.bloomberg.com/quicktake/shadow-banking/.

MARIO QUAGLIARIELLO, Stress-Testing the Banking System: Methodologies And ApPliCAtions 1 (2009).

William J. Rapaport et al., Language and Meaning in Cognitive Science: Cognitive Issues and Semantic Theory 85 (Josefa Toribio \& Andy Clark eds., 1998). 
Regulatory Capital Rules: Regulatory Capital, Implementation of Basel III, Minimum Regulatory Capital Ratios, Capital Adequacy, Transition Provisions, and Prompt Corrective Action, 77 Fed. Reg. 52,791 (proposed Aug. 30, 2012) (to be codified in scattered parts of 12 C.F.R.).

Haocong Ren, Countercyclical Financial Regulation 3 (The World Bank, Working Paper No. 5823, 2011), available at http://elibrary.worldbank.org/doi/pdf/10.1596/1813-9450$\underline{5823}$.

Report to G20 Leaders on monitoring implementation of Basel III regulatory reforms, BASEl COMMITTEE ON BANKING SUPERVISION 1 (Aug. 2013), http://www.bis.org/publ/bcbs260.pdf.

Steven L. Schwarcz,

Derivatives and Collateral: Balancing Remedies and Systemic Risk, UNIVERSITY OF ILLINOIS LAW REVIEW symposium issue (forthcoming 2014-15), available at http://ssrn.com/abstract=2419460.

The Governance Structure of Shadow Banking: Rethinking Assumptions About Limited Liability, 90 NotRE DAME LAW REVIEW (forthcoming 2014-15); available at http://ssrn.com/abstract=2364126.

Intrinsic Imbalance: The Impact of Income Disparity on Financial Regulation, 78:2 LAW AND CONTEMPORARY PROBLEMS (issue no. 2, forthcoming 2015).

Regulating Financial Change: A Functional Approach (2014); available at http://ssrn.com/abstract=2469467.

Ring-Fencing, 87 SOUTHERn CALIFORNIA LAW REVIEW 69 (2013).

Regulating Ex Post: How Law Can Address the Inevitability of Financial Failure (with Iman Anabtawi), 92 TEXAS LAW REVIEW 75 (2013).

Regulating Shadow Banking, 31 REVIEW OF BANKING \& FINANCIAL LAW 619 (2012-13).

The Custom-to-Failure Cycle (with Lucy Chang), 62 DukE LAW JOURNAL 767 (2012).

What is Securitization? And for What Purpose?, 85 SOUTHERn CALIFORNIA LAW REVIEW 1283 (2012).

Marginalizing Risk, 89 WASHINGTON UNIVERSITY LAW REVIEW 487 (2012). 
Regulating Systemic Risk: Towards an Analytical Framework (with Iman Anabtawi), 86 Notre DAME LAW REVIEW 1349 (2011).

Securitization and Structured Finance, ELSEVIER's ENCYCLOPEDIA OF FINANCIAL GLOBALIZATION 6 (2011).

Regulating Complexity in Financial Markets, 87 WASHINGTON UNIVERSITY LAW REVIEW 211 (2009/2010).

Conflicts and Financial Collapse: The Problem of Secondary-Management Agency Costs, 26 Yale Journal On Regulation 457 (Summer 2009).

Keynote Address: Understanding the Subprime Financial Crisis, 60 SOUTH CAROLINA LAW REVIEW 549 (2009).

Disclosure's Failure in the Subprime Mortgage Crisis, 2008 UTAH LAW REVIEW 1109, 1113-15 (2008).

Systemic Risk, 97 GeORgetown LAW JouRnal 193 (2008).

Paul Slovic et al.,

Risk As Analysis and Risk As Feelings: Some Thoughts About Affect, Reason, Risk, and Rationality, 24 RISK ANALYSIS 311, 315 (2004).

Daniel Tarullo,

Governor, Governors of the Federal Reserve System, Speech at the Americans for Financial Reform and Economic Policy Institute Conference, Nov. 22, 2013, available at http://www.federalreserve.gov/newsevents/speech/tarullo20131122a.htm.

BANKING ON BASEL 29 \& 45 (2008).

Halah Touryalai, Top JPMorgan Prop Trader Leaves To Launch Hedge Fund, ForBES (Feb., 15, 2013, 12:48 PM), http://www.forbes.com/sites/halahtouryalai/2013/02/15/top-jpmorgan-proptrader-leaves-to-launch-hedge-fund/.

Robert Weber, A Theory for Deliberation-Oriented Stress Testing Regulation, 98 MINN. L. REV. 2236, 2239 (2014).

Charles Whitehead, The Volcker Rule And Evolving Financial Markets, 1 HARV. Bus. L. REV. 39, 40 (2011). 